\title{
PHYSICAL, CHEMICAL, AND ANTIOXIDANT STABILITY STUDIES OF A TOPICAL FORMULATION CONTAINING POT MARIGOLD (Calendula officinalis L.) FLOWERS EXTRACT
}

Ivan M. Savić*, Ivana M. Savić Gajić

Faculty of Technology in Leskovac, University of Niš, Bulevar oslobođenja 124, 16000 Leskovac, Serbia
(ORIGINAL SCIENTIFIC PAPER)

UDC 633.88:66.061.3

DOI $10.5937 /$ savteh2101011S
Pot marigold flower extract (Calendula officinalis L.) has pharmacological properties due to the presence of various bioactive compounds. It is known that the extract has antioxidant, anti-inflammatory, antitumor, antibacterial, antifungal, antiviral, antimutagenic, antidermatitis properties, etc. The aim of this study was to improve the quality of the selected topical formulation by adding the ethanolic extract of pot marigold flower, as well as to monitor its stability. The topical formulation was water-in-oil emulsion prepared using the hot/hot emulsification process with an oil phase consisting of Vaseline, lanolin, and almond oil. The extract, prepared by ultrasound-assisted extraction, had an antioxidants content of $3.512 \mathrm{~g}$ gallic acid equivalent per $100 \mathrm{~g}^{-1}$ of dry weight and the half-maximal inhibitory concentration of $0.14 \mathrm{mg} \mathrm{mL}^{-1}$ determined by the DPPH assay. Chemical stability studies have shown that daylight has no significant effect on the stability of antioxidants in the extract, while an increase in temperature leads to their degradation. The shelf-life of the extract is about 8 months at $4{ }^{\circ} \mathrm{C}$ and 3 months at 22 ${ }^{\circ} \mathrm{C}$ (room temperature). The prepared uncategorized topical formulations containing $1 \%$ and $2 \%(\mathrm{w} / \mathrm{w})$ pot marigold extract were stable at different temperatures during the storage. The uncategorized formulations showed antioxidant activity, but the activity of the extract in the formulations decreased with increasing storage temperature. Pot marigold flower extract and the developed uncategorized formulations showed an inhibitory effect on Gram-positive (Staphylococcus aureus) and Gram-negative bacteria (Escherichia coli, Proteus mirabilis, Klebsiella pneumoniae), as well as on Candida albicans. The uncategorized formulations with this activity can be used in the treatment of skin infection.
Keywords: extract, emulsion, antioxidant activity, antimicrobial activity, chemical stability, quality control.

\section{Introduction}

Recent studies give favor plant extracts mainly due to the limited use of ingredients of animal origin and the increased demand for organic and sustainable products [1]. Their incorporation into the topical formulations is important since they are a source of vitamins, polyphenols, terpenes, carotenoids, glycosides, saponins, essential oils, and other bioactive compounds. They have beneficial effects on the skin that are usually synergistic $[2,3]$. Bioactive compounds that are applied to the skin work by softening the epidermis, improving blood circulation and enabling rapid epithelialization and regeneration. The topical formulations should be emollient, antiinflammatory, antiseptic, and stimulate skin regeneration. The active ingredients added to the products are mostly herbal extracts (pot marigold, chamomile, etc.) and oils (almond, common evening-primrose, etc.).

Pot marigold flower extract is commonly used in traditional medicine due to the presence of carotenoids, flavonoids, essential oil [4], pentacyclic triterpenes [5], alkaloids, and tannins [6]. The use of this extract is very popular in the development of pharmaceutical and cosmetic products for topical application to the skin [7]. It helps in the synthesis of collagen and the regeneration of skin cells, which makes it suitable for the treatment of wounds [8], rashes, sunburns, inflammatory processes on the skin, insect bites, and other forms of irritations [9]. It is used for the treatment of dry and damaged skin, although it can be used for all skin types. Today, the traditional ointments with ethanolic extract of dried pot marigold flower are still used [10]. The intensive studies have focused on the development of new carriers for the topical application of pot marigold flower extract [11]. The emulsions represent the most suitable carrier so they are commonly used for the preparation of topical formulations with this extract $[12,13]$.

The topical formulations need to be of high quality, safe, effective, stable, and satisfy the criteria of contemporary trends. For these reasons, the use of quality, nat-

\footnotetext{
*Author address: Ivan Savić, Faculty of Technology in Leskovac, University of Niš, Bulevar oslobođenja 124, 16000 Leskovac, Serbia e-mail address: savicivan@tf.ni.ac.rs; ici_teh@yahoo.com The manuscript received: March, 20, 2020.

Paper accepted: April, 27, 2021.
} 
ural, and biodegradable raw materials is recommended. It is necessary to conduct characterization and evaluation of physical and chemical stability of topical formulations with herbal extracts $[14,15]$. The tests of physical and chemical stability of the formulation have become important parameters that should be taken into account during the preparation, storage, and use of the product [7]. The aim of this study was to improve the properties of water-in-oil (w/o) emulsion (hydrophobic formulation), prepared using the hot/hot emulsification process with an oil phase consisted of Vaseline, lanolin, and almond oil, by the incorporation of pot marigold flower extract in different concentrations. The formulations were subjected to physical and chemical stability tests to determine the storage life and shelf-life of the products. The functional stability of the formulations was also monitored to evaluate the effect of the formulation composition on the activity of pot marigold flower extract.

\section{Experimental}

\section{Materials}

In this study, 96\% (v/v) ethanol (Zorka Pharma, Sabac, Serbia), 2,2-diphenyl-1-picrylhydrazyl (DPPH), butylhydroxytoluene (BHT) (Sigma Chemical, St. Louis, Missouri, USA), Folin-Ciocalteu reagent, and gallic acid (97\%) (Merck, Darmstadt, Germany) were used. The used excipients for the preparation of the w/o emulsion were: white petrolatum (white Vaseline, Vaselinum album) (Tehno-chem, Serbia), lanolin (Adeps lanae), boric acid (Sigma Aldrich, Serbia), almond water (Aqua Amygdalae Amarae), and almond oil (Oleum Amygdalae Amarae) (Sigma Chemical, St. Louis, Missouri, USA). All other chemicals were pro analysis grade.

\section{Plant material}

Pot marigold (Calendula officinalis L.) flowers were purchased from Dr. Josip Pancic (Belgrade, Serbia). The moisture content of $14.36 \%$ (w/w) was determined by drying plant material at $105^{\circ} \mathrm{C}$ to constant weight. The dried pot marigold flowers were ground using an electric mill.

\section{Preparation of the extract}

Pot marigold flower extract was prepared by ultrasound-assisted extraction according to the procedure described by Zerajic et al. [16]. The ground plant material $(5.0 \mathrm{~g})$ was extracted with $40 \%$ (v/v) ethanol $(100 \mathrm{~mL}$ $\left.\mathrm{g}^{-1}\right)$ at $65{ }^{\circ} \mathrm{C}$ for $30 \mathrm{~min}$. After the extraction, the solids were separated from the liquid phase by vacuum filtration on a Büchner funnel. The dry matter content of the extract was determined by drying an aliquot of $3 \mathrm{~mL}$ in a laboratory oven at $105^{\circ} \mathrm{C}$. Residual liquid extract was stored at $4{ }^{\circ} \mathrm{C}$ in the fridge for further analyses.

\section{Preparation of topical formulations}

The topical formulations (w/o emulsion) with $1 \%$ and $2 \%$ of pot marigold flower extract (F1 and F2, respec- tively) and cream base were prepared using the hot/hot emulsification process. The oil phase, which consisted of vaseline and lanolin, was heated in an enameled paten using a water bath at $50 \pm 1{ }^{\circ} \mathrm{C}$. Almond water was heated to the same temperature, to which different concentrations of ethanol extract were added. After heating, the aqueous phase was gradually added to the oil phase

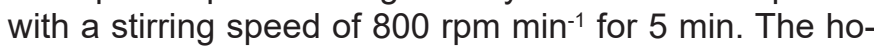
mogenization was continued at a stirring speed of 500 rpm $\min ^{-1}$ to below $40{ }^{\circ} \mathrm{C}$ when almond oil was added to the mixture. Stirring was continued until the emulsion was cooled to $22{ }^{\circ} \mathrm{C}$ (room temperature). The prepared samples were stored in a polypropylene plastic container. The cream base was prepared in the same way but without the addition of the pot marigold flower extract. The composition of topical formulations with and without pot marigold flower extract is given in Table 1.

Table 1. The composition of formulations with or without the addition of the pot marigold flower extract

\begin{tabular}{lccc}
\hline \multicolumn{1}{c}{ Ingredients } & Cream base & F1 & F2 \\
\hline White Vaseline & $30 \mathrm{~g}$ & $30 \mathrm{~g}$ & $30 \mathrm{~g}$ \\
Lanolin & $30 \mathrm{~g}$ & $30 \mathrm{~g}$ & $30 \mathrm{~g}$ \\
Almond oil & $5 \mathrm{~g}$ & $4 \mathrm{~g}$ & $3 \mathrm{~g}$ \\
Boric acid, 3\% & $25 \mathrm{~g}$ & $25 \mathrm{~g}$ & $25 \mathrm{~g}$ \\
Almond water & $10 \mathrm{~g}$ & $10 \mathrm{~g}$ & $10 \mathrm{~g}$ \\
Pot marigold flower extract & - & $1 \mathrm{~g}$ & $2 \mathrm{~g}$ \\
\hline
\end{tabular}

Methods for the evaluation of the antioxidant capacity of the pot marigold flower extract

Folin-Ciocalteu reagent assay

Folin-Ciocalteu reagent assay (FCR) was used to estimate the reducing capacity of the ethanolic extract of pot marigold flower [17]. Gallic acid was used as a standard for the construction of the calibration curve to express the reducing capacity (grams gallic acid equivalent per $100 \mathrm{~g}$ of dry weight, g GAE $100 \mathrm{~g}^{-1} \mathrm{~d}$.w.). The procedure is based on the tenfold dilution of Folin-Ciocalteu reagent and its addition $(1 \mathrm{~mL})$ into $0.1 \mathrm{~mL}$ of the extract. After a few minutes, $1 \mathrm{~mL}$ of $7 \%(\mathrm{w} / \mathrm{v})$ sodium carbonate was added to the sample. The sample was stored in a dark place for $90 \mathrm{~min}$. The absorbance was measured at $765 \mathrm{~nm}$ on a Varian Cary 100 UV-Vis spectrophotometer (Mulgrave, Victoria, Australia).

\section{DPPH assay}

The antioxidant activity of the extract was determined using the DPPH assay [17]. The solution of DPPH radicals $\left(3 \times 10^{-4} \mathrm{~mol} \mathrm{~L}^{-1}\right)$ was prepared and $1 \mathrm{~mL}$ in $2.5 \mathrm{~mL}$ of extract solution was added. Instead of the extract solution, the negative control solution contained the equivalent amount of $96 \%$ (v/v) ethanol. The blank solution consisted of $1 \mathrm{~mL}$ of ethanol and $2.5 \mathrm{~mL}$ of the extract. The scanning of the samples was carried out at $517 \mathrm{~nm}$ after 30 min of incubation. The percentage of DPPH radicals 
inhibition $\left(I_{D P P H}\right)$ was calculated according to Equation 1:

$$
I_{\text {DPPH }}[\%]=\frac{A_{c}-\left(A_{s}-A_{B}\right)}{A_{c}} \cdot 100
$$

where are, $A_{C}$ - absorbance of the control solution, $A_{B}$ - absorbance of the blank solution, and $A_{S}$ - absorbance of the sample. The antioxidant activity of the samples was estimated on the basis of the half-maximal inhibitory concentration $\left(\mathrm{IC}_{50}\right.$ value) obtained by interpolation as a function of the inhibition of DPPH radicals and the sample concentration.

Testing quality of the topical formulations

Organoleptic tests

The organoleptic properties of cream base and formulations, such as appearance, color, shine, homogeneity, and phase separation were estimated by visual observation. The applicative and sensory properties of the topical formulations (ease of smearing, absorbency, stickiness, greasiness of the film on the skin) were evaluated after their application to the skin. The tests were performed $24 \mathrm{~h}$ after the preparation of the formulations.

Determination of the type of emulsion by measuring electrical conductivity

The electrical conductivity was measured by directly immersing the conductometer electrode (CDM 230, Radiometer, Copenhagen, Denmark) in the samples at $22^{\circ} \mathrm{C}$ (room temperature). The measuring electrode was calibrated with $0.01 \mathrm{~mol} \mathrm{~L}^{-1} \mathrm{KCl}$ solution.

\section{Determination of $\mathrm{pH}$ values}

The $\mathrm{pH}$ value of the aqueous phase at $22{ }^{\circ} \mathrm{C}$ (room temperature) was measured after dissolving $5 \mathrm{~g}$ of the sample in $25 \mathrm{~mL}$ of water and heating at $60{ }^{\circ} \mathrm{C}$ for 10 min. Before starting, the instrument was calibrated with standard $\mathrm{pH}$ buffers of 4.0 and 7.0. A pH meter $(\mathrm{HI} 9321$, Hanna Instruments, Lisbon, Portugal) was used.

\section{Viscosity}

The viscosity of the prepared formulations was determined using a viscometer (Visco basic plus, Fungilab, Hapog, New York, USA) at a rotational speed of $12 \mathrm{rpm}$ $\mathrm{min}^{-1}$ using an SP-R5 spindle.

The chemical stability of the extract and formulations

The chemical stability of the extract and formulations was monitored at different temperatures: $4{ }^{\circ} \mathrm{C}, 22{ }^{\circ} \mathrm{C}$ (room temperature), and $40{ }^{\circ} \mathrm{C}$ in daylight or darkness for 3 months. The content of antioxidants was monitored spectrophotometrically using the FCR assay by measuring the absorbance at $765 \mathrm{~nm}$. After exposure of 7 , 30, 60, and 90 days, the FCR was determined for each sample and expressed as milligrams GAE per milliliter. The thermal degradation of antioxidants in pot marigold flower extract was described using the first-order kinetics (Equation 2).
$C=C_{0} e^{-k_{1} t}$

where, $C$ - the concentration in time $t, C_{0}$ - the initial concentration of the sample, and $k_{1}$ - the first-order rate constant.

The shelf-life $\left(t_{90}\right)$ of the extract and formulations for the first-order was calculated according to Equation 3:

$$
\begin{aligned}
t_{90} & =\frac{0.105}{k_{1}} \\
& \text { Physical stability of the topical formulations } \\
& \text { Centrifugation test }
\end{aligned}
$$

The cream base samples, F1 and F2 $(4 \mathrm{~g})$ were placed into $10 \mathrm{~mL}$ plastic test tubes and centrifuged twice at $3,000 \mathrm{rpm}$ for $15 \mathrm{~min}$. The samples were centrifugated in a laboratory centrifuge (LC 320, Libra, Železniki, Slovenia) at $22{ }^{\circ} \mathrm{C}$ (room temperature) for $24 \mathrm{~h}$ after the preparation of the formulations. Each sample was inspected visually to detect any changes, i.e. phase separation.

Accelerated stability test

The samples of topical formulations were stored at $4{ }^{\circ} \mathrm{C}, 22^{\circ} \mathrm{C}$, and $40^{\circ} \mathrm{C}$ for 1 month. The $\mathrm{pH}$ value of the samples were monitored after $1,7,15$, and 30 days.

Long-term stability test

The long-term stability of the formulations was estimated based on the organoleptic tests and changes in electrical conductivity and $\mathrm{pH}$ values. The samples were stored at $22{ }^{\circ} \mathrm{C}$ (room temperature) for 3 months. The sampling was carried out after $7,30,60$, and 90 days of storage.

Antioxidant activity of the extract and functional stability of re-extracted antioxidants from topical formulations

The antioxidant activity of the extract was determined using the DPPH assay before and after its incorporation into the formulations. The cream base was also analyzed according to this procedure. The formulations were dispersed in ethanol to obtain the same concentration of extract used for the analysis $\left(10 \mathrm{mg} \mathrm{mL}^{-1}\right)$. The extract and formulations were stored at $22{ }^{\circ} \mathrm{C}$ (room temperature) for 3 months [18]. The functional stability of the extract and formulations was defined based on the change in antioxidant activity during storage time.

\section{Microbiological safety}

The method is based on the isolation and identification of bacteria, yeasts, and mold present in the sample according to the cosmetics regulations [19]. The samples were seeded on a nutrient medium and incubated under optimal conditions. A product is considered microbiologically safe if the total number of aerobes is less than $10^{2}$ aerobic bacteria and fungi; enterobacteria and other Gram-negative bacteria less than 10; no Pseudomonas aeruginosa and Staphylococcus aureus in $1 \mathrm{~g}$ of product. 
Antimicrobial activity of extracts and topical formulations

Antimicrobial activity of pot marigold flower extract and topical formulations was studied in vitro on Grampositive bacteria (Staphylococcus aureus ATCC 6538, Streptococcus pneumoniae ATCC 49619), Gram-negative bacteria (Escherichia coli ATCC 8739, Proteus mirabilis ATCC 25933, Klebsiella pneumoniae ATCC 10031), and fungus (Candida albicans ATCC 10231) using a disk diffusion method. The test samples were dissolved in dimethyl sulfoxide (DMSO). The antibiotic medium no. 1 was used for bacterial growth, while Sabouraud 4\% Dextrose Agar was used for fungal growth. The nutrient medium was dissolved in warm purified water and then sterilized in an autoclave at $121{ }^{\circ} \mathrm{C}$ for $15 \mathrm{~min}$. The sterilized medium was then cooled to $40-45^{\circ} \mathrm{C}$. The suspension of microorganisms was inserted in the medium and then poured into Petri dishes. The paper discs $(6 \mathrm{~mm}$ in diameter) were soaked with $30 \mu \mathrm{L}$ of the extract (11.55 $\left.\mathrm{mg} / \mathrm{mL}^{-1}\right)$ and the sample $\left(0.1 \mathrm{~g} \mathrm{~mL}^{-1}\right)$. Gentamicin was used as a positive control, while DMSO was used as a negative control. The bacteria were incubated at $37^{\circ} \mathrm{C}$ for $18-24 \mathrm{~h}$, while the fungi were incubated at $25^{\circ} \mathrm{C}$ for $24-48 \mathrm{~h}$ under anaerobic conditions.

\section{Statistical analysis}

All obtained data are presented as the mean value of three measurements.

\section{Results and discussion}

Characterization of pot marigold flower extract

In the literature, the total polyphenolic content was mostly described as a reaction between Folin-Ciocalteu reagent and polyphenols, although this reagent can react with various bioactive compounds [20]. According to that, the proper term is the FCR. In this case, the FCR of $3.512 \mathrm{~g} \mathrm{GAE} 100 \mathrm{~g}^{-1} \mathrm{~d}$.w. was determined for pot marigold flower extract using the spectrophotometric method. Hernández-Rosas et al. [21] determined the FCR of $37.01 \mathrm{mg} \mathrm{GAE} \mathrm{g}^{-1}$ for $70 \%(\mathrm{v} / \mathrm{v}$ ) ethanolic extract of pot marigold flower prepared by maceration with stirring for $48 \mathrm{~h}$. The slight differences in the FCR can be attributed to the plant growing conditions, extraction conditions, and extraction techniques.
Antioxidant activity of pot marigold flower extract

The maximum DPPH radicals inhibition of $95 \%$ was achieved at the concentration of $0.63 \mathrm{mg} \mathrm{mL}^{-1}$ for the extract, i.e. $80 \%$ at the concentration of $0.12 \mathrm{mg} \mathrm{mL}^{-1}$ for the synthetic antioxidant BHT after 30 min of incubation. In the literature, the aqueous extract of pot marigold flower prepared by maceration for $24 \mathrm{~h}$ shows maximum antioxidant activity at the concentration of $0.9 \mathrm{mg} \mathrm{mL}^{-1}$ after 2 min of incubation [22]. The reason for differences in antioxidant activity is probably due to the use of different incubation times, extraction technique, and solvents. The $\mathrm{IC}_{50}$ value of $0.14 \mathrm{mg} \mathrm{mL}^{-1}$ obtained for the extract was higher compared to the $\mathrm{IC}_{50}$ of $0.04 \mu \mathrm{g} \mathrm{mL} \mathrm{L}^{-1}$ for BHT. Even though BHT was a better antioxidant, today's trend in the cosmetics industry favors the use of natural antioxidants. Given this fact, ethanol extract can be used as a source of natural antioxidants for the preparation of topical formulations.

Antimicrobial activity of the extract

The antimicrobial activity of pot marigold flower extract $\left(11.55 \mathrm{mg} \mathrm{mL}^{-1}\right)$ was analyzed against different microorganism strains. The results of antimicrobial activity are shown in Table 2. The microbial strains were resistant to the effect of DMSO, while gentamicin as a positive control only affected the growth of Gram-positive and Gram-negative bacteria. The extract showed antimicrobial activity against Gram-positive (S. aureus) and Gram-negative bacteria (E. coli, P. mirabilis, and K. pneumoniae), while its effect on Gram-positive bacterium S. pneumonia was not observed. The best inhibitory effect of the extract was noticed against $E$. coli that belongs to the group of resistant bacteria. It also showed an effect against $C$. albicans. These results are consistent with the available results $[6,23]$. The antimicrobial activity of the extract enables its use as an agent in the treatment of skin infections caused by these microbes. In this way, the development of serious disorders on the skin can be prevented.

Table 2. The results of antimicrobial activity determined using a disk diffusion method

\begin{tabular}{lcccccc}
\hline Microorganisms & extract & F1 & F2 & Cream base & DMSO & Gentamicin \\
\hline S. aureus & ++ & + & ++ & - & - & +++ \\
S. pneumoniae & - & - & - & - & - & +++ \\
E. coli & ++++ & +++ & ++++ & - & - & ++ \\
P. mirabilis & ++ & ++ & ++ & - & - & ++ \\
K. pneumoniae & ++ & + & ++ & - & - & + \\
C. albicans & +++ & ++ & ++ & - & - & - \\
\hline
\end{tabular}

The inhibition zone: $<15 \mathrm{~mm}(-), 15-16 \mathrm{~mm} \mathrm{(+),} \mathrm{17-19} \mathrm{mm} \mathrm{(++),} \mathrm{20-22} \mathrm{mm} \mathrm{(+++),} \mathrm{>23} \mathrm{mm} \mathrm{(++++).} \mathrm{Standard} \mathrm{deviation}$ $\pm 0.5 \mathrm{~mm}$ 
Chemical stability of the extract

The temperature is a key factor in the degradation of active substances and affects the formation of hazardous products or acceleration of this process. Therefore, the chemical stability of the pot marigold flower extract was monitored at three different temperatures: $4{ }^{\circ} \mathrm{C}$, $22{ }^{\circ} \mathrm{C}$, and $40{ }^{\circ} \mathrm{C}$ for 90 days. In the sample of extract stored at $4{ }^{\circ} \mathrm{C}$, a significant change in reducing capacity was not noticed, most likely due to the inhibition of phenoloxidase activity [24]. The reduction in the FCR was about $10 \%$ for the extracts stored at $22{ }^{\circ} \mathrm{C}$ and $40{ }^{\circ} \mathrm{C}$ after 90 days. It is known that the stability of polyphenols is greater at lower temperatures [25]. The rate constant of antioxidants degradation according to Equation 2 is depicted in Table 3 . The maximum value of the degradation rate constant $\left(10.6 \times 10^{-4}\right.$ day $\left.^{-1}\right)$ was reached at $40^{\circ} \mathrm{C}$, while the lowest one $\left(4.63 \times 10^{-4}\right.$ day $\left.^{-1}\right)$ was reached at $4{ }^{\circ} \mathrm{C}$. The obtained results indicated that the increase in temperature leads to faster degradation of antioxidants in the extract.

Table 3. The kinetic parameters of thermal degradation of antioxidants in the extract

\begin{tabular}{lcc}
\hline \multirow{2}{*}{ Temperature $\left({ }^{\circ} \mathbf{C}\right)$} & \multicolumn{2}{c}{ First-order } \\
& $\boldsymbol{k}_{\mathbf{1}} \times \mathbf{1 0 ^ { 4 }}\left(\right.$ day $\left.^{-1}\right)$ & $\mathbf{R}^{\mathbf{2}}$ \\
\hline 4 & 4.63 & 0.989 \\
22 & 9.62 & 0.986 \\
40 & 10.60 & 0.982 \\
\hline
\end{tabular}

Having in mind that the degradation of antioxidants follows the first-order kinetics [26], the shelf-life of the extract was calculated according to Equation 3. It was 7.5 months at $4{ }^{\circ} \mathrm{C}, 3.6$ months at $22^{\circ} \mathrm{C}$, and 3.3 months at $40{ }^{\circ} \mathrm{C}$. The temperature had a significant effect on the stability of the extract. Bilia et al. [27] obtained similar data by studying the chemical stability of two different ethanolic extracts of pot marigold flower, prepared according to the pharmacopoeial procedure, by accelerated and long-term tests. They concluded that the solvent used for the extraction affected the stability of the extract. The shelf-life of $60 \%(\mathrm{v} / \mathrm{v})$ ethanolic extract was longer than 5 months and shorter than 4 months for $40 \%$ (v/v) ethanolic extract. The chemical stability of the pot marigold flower extract was evaluated taking into account the change of FCR during storage in daylight and darkness for 90 days. It was found that daylight does not have a significant impact on the degradation of antioxidants, since the change in their content was relatively small (about 3\%). The obtained results enabled the selection of excipients to formulate the topical formulation and define the storage conditions of the product.

Topical formulations with pot marigold flower extract

The choice of carrier represents the important step in the formulation of topical products with herbal extracts. It affects the penetration of bioactive compounds through the skin and the loss of their activity over time. Having in mind that the emulsions are the most suitable type of carrier, one of them was used for the preparation of topical formulations with pot marigold flower extract. The oil phase of the hydrophobic formulations (w/o emulsions) consisted of white Vaseline, lanolin, and almond oil. These ingredients commonly reduce the transepidermal water loss, i.e. they slow down its drying. Almond oil is rich in vitamins $A, B, D$, and $E$, minerals, and essential fatty acids [28]. It helps maintain normal skin moisture, nourishes and softens the skin, reduces skin redness, and strengthens its resistance to external influences [29]. Lanolin was used as an emulsifier, but it can be also used as an antibacterial agent [30, 31]. In addition to the ingredients of the oil phase, the formulations contained a $3 \%(w / v)$ boric acid solution and almond water. Boric acid acts as an antiseptic and is used to soothe inflammatory processes on the skin [32]. The pleasant odor of the formulations originated from almond water. The formulations were prepared without the addition of preservatives, fragrances, and colors. The developed topical formulations can be used as mild antiseptics due to the presence of pot marigold flower extract. They form a thin protective layer on the skin that protects it from adverse environmental conditions. The advantage of these formulations is the absence of zinc oxide and talc that have astringent and adsorbent effects. Akhtar et al. [13] also developed a hydrophobic formulation with ethanolic extract of pot marigold flower $(3 \%)$. The oil phase consisted of paraffin oil (16\%) and surfactant ABIL-EM 90 (cetyl dimethicone copolyol with HLB 5) (3.5\%). Almond oil was added dropwise to improve the odor of the formulation. The formulation showed moisturizing and antiinflammatory effects.

\section{Quality testing of the topical formulations}

Organoleptic testing

The organoleptic properties of the cream base and formulations were determined $24 \mathrm{~h}$ after their preparation. The topical formulations with a characteristic odor were homogeneous and of semi-solid consistency. The proper selection of the oil phase ingredients and mixing speed enabled the samples to be stable $24 \mathrm{~h}$ after preparation. The formulations were easily smeared on the skin, leaving a greasy film that was not sticky.

\section{Determination of the emulsion type}

The electrical conductivity of the cream base was 1 $\mu \mathrm{S} \mathrm{cm}^{-1}$, while the electrical conductivity of F1 and F2 were $3 \mu \mathrm{S} \mathrm{cm}^{-1}$ and $4 \mu \mathrm{S} \mathrm{cm}^{-1}$, respectively. The low electrical conductivity implied that the formulations were w/o emulsions. Also, the addition of the extract in the cream base did not significantly cause the change in the electrical conductivity.

Determination of $\mathrm{pH}$ values

The $\mathrm{pH}$ value of the cream base was decreased from 
5.86 to 5.81 and 5.78 for F1 and F2, respectively. This behavior was in accordance with the data reported by Akhtar et al. [13]. Since the pH values of the skin were in the allowable range of $3.5-8.0$, the prepared formulations can be considered safe for use.

\section{Viscosity}

The viscosity of the formulations was important during the determination of the formulation consistency and evaluation of the product stability. The viscosity of the cream base, F1, and F2 was 39.5, 38.3, and $37.2 \mathrm{~Pa}$ s, respectively. Based on these values, it can be concluded that the formulations were of semi-solid consistency. The addition of the extract to the cream base resulted in a decrease in viscosity [33]. This is most likely caused by the internal layering in the formulation. Anchisi et al. [34] showed that the viscosity can be reduced by about $20 \%$ after adding the plant extract to the cream base.

\section{Stability study of the formulations}

The change in the FCR was monitored during the analysis of the chemical stability of the formulations. In the physical stability study, the appearance (organoleptic) and parameters characterizing the pharmaceutical-technological properties of the topical formulations (phase separation, $\mathrm{pH}$ value, and electrical conductivity) were also analyzed. The functional stability of the formulations was evaluated due to the change in antioxidant activity during storage. These studies were key to define the storage conditions and shelf-life of the products.

\section{Chemical stability of the topical formulations}

The change in the FCR was a key parameter for the estimation of the chemical stability of the extract after its incorporation into the topical formulations. The FCR was reduced by less than $5 \%$ after 3 months of storage, indicating the satisfactory stability of the extract in the formulations. The changes in antioxidants content in the formulations corresponded to the first-order reaction. The reaction rate constants at $22{ }^{\circ} \mathrm{C}$ for $\mathrm{F} 1$ and $\mathrm{F} 2$ were $4.846 \times 10^{-4}$ day $^{-1}$ and $4.640 \times 10^{-4}$ day $^{-1}$, respectively. The shelf-life of developed F1 and F2, calculated according to Equation 3, was about 8 months at $22{ }^{\circ} \mathrm{C}$ (room temperature). Since the shelf-life of the extract was about 3 months, it is obvious that the improvement in the chemical stability was achieved after its incorporation into the formulations. The satisfactory stability of the extract in the formulations was the result of the proper selection of their ingredients, especially the ingredients of the oil phase.

\section{Physical stability of the topical formulations}

Centrifugation test

The prepared formulations and cream base showed satisfactory physical stability because under the influence of mechanical stress there was no phase separation.

\section{Accelerated stability test}

The $\mathrm{pH}$ values of cream base and formulations stored at different temperatures for 30 days are depicted in Table 4. The $\mathrm{pH}$ values of the cream base stored at $4{ }^{\circ} \mathrm{C}$ were increased until day 14 and then decreased. The $\mathrm{pH}$ values of the sample stored at $22^{\circ} \mathrm{C}$ were increased with slight deviations. At $40{ }^{\circ} \mathrm{C}$, the $\mathrm{pH}$ values were gradually increased for 7 days and then decreased continuously until day 30 with some deviations. At the end of this analysis, the $\mathrm{pH}$ values of the cream base at $4{ }^{\circ} \mathrm{C}, 22^{\circ} \mathrm{C}$, and $40^{\circ} \mathrm{C}$ were $5.89,6.33$, and 5.54 , respectively.

Table 4. The changes in the $\mathrm{pH}$ values of cream base and formulations stored at different temperatures

\begin{tabular}{lccccccccc}
\hline \multirow{2}{*}{ Time (day) } & \multicolumn{3}{c}{$\mathbf{4}^{\circ} \mathbf{C}$} & \multicolumn{3}{c}{$\mathbf{2 2}{ }^{\circ} \mathbf{C}$} & \multicolumn{3}{c}{$\mathbf{4 0}{ }^{\circ} \mathbf{C}$} \\
& B & F1 & F2 & B & F1 & F2 & B & F1 & F2 \\
\hline 0 & 5.86 & 5.81 & 5.78 & 5.86 & 5.81 & 5.78 & 5.86 & 5.81 & 5.78 \\
1 & 6.25 & 6.02 & 5.89 & 6.28 & 5.85 & 5.79 & 6.01 & 5.83 & 5.73 \\
7 & 6.32 & 6.08 & 5.91 & 6.31 & 5.93 & 5.84 & 5.73 & 5.78 & 5.89 \\
15 & 6.47 & 5.88 & 5.90 & 6.07 & 5.77 & 5.76 & 5.52 & 5.72 & 5.71 \\
30 & 5.89 & 5.91 & 5.93 & 6.33 & 5.69 & 5.66 & 5.54 & 5.63 & 5.62 \\
\hline
\end{tabular}

B - cream base, F1 - formulation with $1 \%$ of the pot marigold extract, $\mathbf{F} 2$ - formulation with $2 \%$ of the pot marigold extract

The $\mathrm{pH}$ values of $\mathrm{F} 1$ and $\mathrm{F} 2$ stored at $22^{\circ} \mathrm{C}$ and $40^{\circ} \mathrm{C}$ gradually increased until day 7 , after which it began to decline over time with slight deviations. At $4{ }^{\circ} \mathrm{C}$, the $\mathrm{pH}$ values of $\mathrm{F} 1$ and $\mathrm{F} 2$ gradually increased. At the end of day 30 , the $\mathrm{pH}$ values of $\mathrm{F} 1$ were $5.91,5.69$, and 5.63 at $4{ }^{\circ} \mathrm{C}, 22^{\circ} \mathrm{C}$, and $40^{\circ} \mathrm{C}$, respectively, while the $\mathrm{pH}$ values of $\mathrm{F} 2$ were $5.93,5.66$, and 5.62 , respectively. The decrease in $\mathrm{pH}$ values of the formulations at $22{ }^{\circ} \mathrm{C}$ and 40 ${ }^{\circ} \mathrm{C}$ may be due to the production of any acidic metabolite or the decomposition of any ingredient. The $\mathrm{pH}$ values of all samples after 30 days of storage at different temperatures remained in the allowed $\mathrm{pH}$ range of the skin. Slight changes in the $\mathrm{pH}$ values of the base and formulations as functions of time and temperature indicated that the tested samples were stable.

\section{Long-term stability of the topical formulation}

The values of $\mathrm{pH}$ and electrical conductivity of the cream base and formulations stored at $22{ }^{\circ} \mathrm{C}$ (room temperature) for $7,30,60$, and 90 days are presented in Table 5.

The $\mathrm{pH}$ values were in the range $6.26-6.36$ for the cream base, 5.72 - 5.89 for F1, and 5.66 - 5.84 for F2. The $\mathrm{pH}$ values for all samples after 90 days were in the allowed $\mathrm{pH}$ range of the skin. In contrast to the $\mathrm{pH}$ values, there was an increase in electrical conductivity over time. The prepared formulations remained w/o emulsion since their electrical conductivities were lower than 50 $\mu \mathrm{S} \mathrm{cm}{ }^{-1}$. After 90 days of storage, there were no visible changes in appearance, color, and spreadability in the topical formulations. No significant changes in $\mathrm{pH}$, electrical conductivity, and organoleptic properties were observed, indicating that the formulations were stable at $22^{\circ} \mathrm{C}$ (room temperature) over time. 
Table 5. The change in $\mathrm{pH}$ value and electrical conductivity of cream base and formulations stored at room temperature $\left(22^{\circ} \mathrm{C}\right)$

\begin{tabular}{lcccccccc}
\hline \multirow{2}{*}{ Sample } & \multicolumn{4}{c}{ pH } & \multicolumn{4}{c}{ Electrical conductivity $\left(\boldsymbol{\mu S} \mathbf{~ c m}^{-1}\right)$} \\
& $\mathbf{7}$ day & 30 day & $\mathbf{6 0}$ day & $\mathbf{9 0}$ day & $\mathbf{7}$ day & $\mathbf{3 0}$ day & $\mathbf{6 0}$ day & $\mathbf{9 0}$ day \\
\hline B & 6.26 & 6.30 & 6.34 & 6.36 & 1 & 2 & 3 & 3 \\
F1 & 5.89 & 5.72 & 5.81 & 5.88 & 3 & 4 & 3 & 4 \\
F2 & 5.84 & 5.66 & 5.74 & 5.79 & 4 & 3 & 4 & 5 \\
\hline
\end{tabular}

Antioxidant activity of the extract and functional stability of re-extracted antioxidants from topical formulations The $\mathrm{IC}_{50}$ value $\left(0.14 \mathrm{mg} \mathrm{mL}^{-1}\right)$ of the extract did not differ significantly from the $\mathrm{IC}_{50}$ value $\left(0.15 \mu \mathrm{g} \mathrm{mL}^{-1}\right)$ of the extract re-extracted from the formulations. The excipients used to prepare the formulations did not alter the antioxidant activity of the extract. The functional stability of the extract, F1, and F2 stored at different temperatures for 3 months was carried out by monitoring the change in the antioxidant activity. There were no significant changes in the antioxidant activity of the pot marigold extract at $4{ }^{\circ} \mathrm{C}, 22{ }^{\circ} \mathrm{C}$, and $40{ }^{\circ} \mathrm{C}$ (Figure 1a). Some deviations can be attributed to an error during the determination of antioxidant activity (coefficient of variation $=5 \%$ ). The slight change in the antioxidant activity of the extract was the result of the significant stability of antioxidants. In the F1 and F2, the antioxidant activity of the extract was not significantly changed at $4{ }^{\circ} \mathrm{C}$ and $22{ }^{\circ} \mathrm{C}$ (Figure $1 \mathrm{~b}$ and $\mathrm{C}$ ). The loss of the activity of the extracts at $40{ }^{\circ} \mathrm{C}$ was about $8 \%$ in the $\mathrm{F} 1$ and $\mathrm{F} 2$ (Figure $1 \mathrm{~b}$ and $\mathrm{c})$. The reduction of antioxidant activity of the extract in the topical formulations was probably due to the degradation of antioxidants.
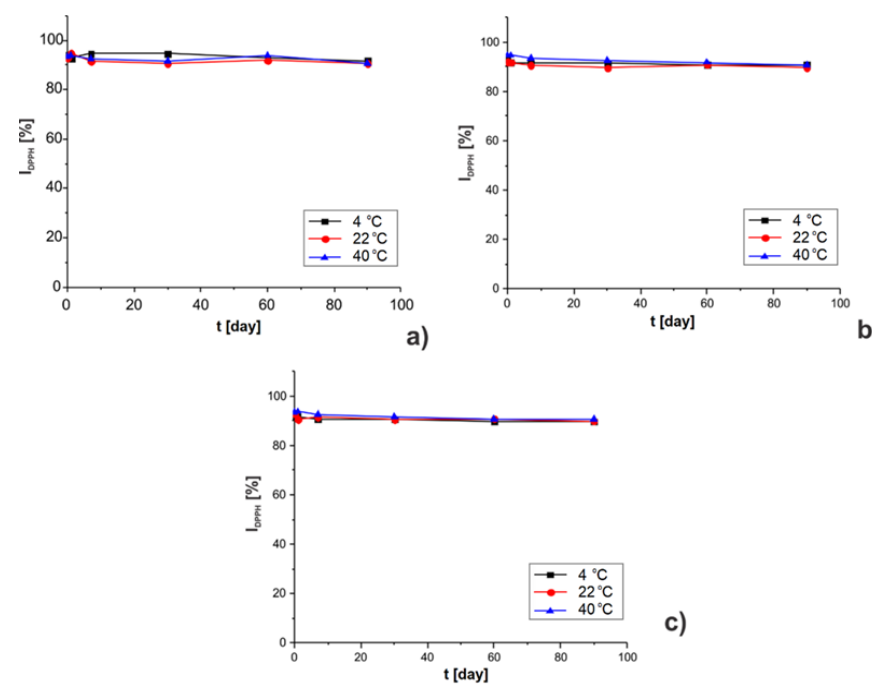

Figure 1. The change in the antioxidant activity over time of: a) ethanolic extract, b) F1, and c) F2 at different temperatures

Polypropylene container is the lightweight and economical packaging material that can protect the product from heat and moisture. Given this fact, it is recommended to pack the prepared formulations. The product should be stored in a cool place or at a controlled room temperature and long-term exposure to temperatures above $30^{\circ} \mathrm{C}$ should be avoided.

Microbiological safety of the topical formulations

The formulations were microbiologically safe because the total number of aerobic bacteria, yeast, and mold spores in $1 \mathrm{~g}$ of the sample was in accordance with the regulations [19]. The presence of pathogenic bacteria was not confirmed in the samples.

Antimicrobial activity of the topical formulations

The results of antimicrobial activity of cream base and formulations $\left(0.1 \mathrm{~g} \mathrm{~mL}^{-1}\right)$ are depicted in Table 2. The cream base did not show inhibitory activity against the used strains of microorganisms. The developed formulations showed antimicrobial activity against Gram-positive (S. aureus) and Gram-negative bacteria (E. coli, P. mirabilis, and K. pneumoniae). The samples did not affect S. pneumoniae, while their activity was significant against E. coli. Pazhohideh et al. [35] showed that the topical formulation with pot marigold extract is effective in the treatment of bacterial vaginosis in women of reproductive age, without any side effects. Saffari et al. [36] confirmed that the Calendula vaginal cream is effective in the treatment of vaginal candidiasis. Compared to the synthetic drug clotrimazole, the formulation has a greater long-term effect.

\section{Conclusion}

The ethanolic extract of pot marigold flower with the FCR of $3.512 \mathrm{~g} \mathrm{GAE} 100 \mathrm{~g}^{-1}$ d.w. and expressed antioxidant $\left(\mathrm{IC}_{50}\right.$ value of $\left.0.14 \mathrm{mg} \mathrm{mL}^{-1}\right)$ and antimicrobial activities (E. coli, C. albicans, S. aureus, P. mirabilis, $K$. pneumoniae) was used to improve the properties of hydrophobic formulations (w/o emulsion). The results of chemical stability indicated that the extract was more stable at lower temperatures $\left(4^{\circ} \mathrm{C}\right.$ and $\left.22{ }^{\circ} \mathrm{C}\right) \mathrm{com}$ pared to higher temperatures $\left(40{ }^{\circ} \mathrm{C}\right)$. The prepared uncategorized formulations with the addition of $1 \%$ and $2 \%$ of the extract were stable during storage at different temperatures probably due to the proper selection of the formulation ingredients. They were of semi-solid consistency, homogeneous, free of synthetic odors, colors, and preservatives. The stability studies indicated that the formulations should be stored in a cool place or at controlled room temperature, avoiding prolonged exposure to temperatures above $30^{\circ} \mathrm{C}$. The microbiological analysis confirmed that the cream base and uncategorized formulations were microbiologically safe. Taking into con- 
sideration these findings, it can be concluded that both uncategorized formulations (F1 and F2) are suitable for topical application in the treatment of various skin infections.

\section{Acknowledgments}

The Republic of Serbia - Ministry of Education, Science and Technological Development, Program for financing scientific research work, number 451-039/2021-14/200133.

\section{References}

[1] B. Fonseca-Santos, M. A. Correa, M. Chorilli, Sustainability, natural and organic cosmetics: consumer, products, efficacy, toxicological and regulatory considerations, Brazilian Journal of Pharmaceutical Sciences, 51(1) (2015) 17-26.

[2] O. Taofiq, S. A. Heleno, R. C. Calhelha, M. J. Alves, L. Barros, A. M. González-Paramás, M. F. Barreiro, I. C. Ferreira, The potential of Ganoderma lucidum extracts as bioactive ingredients in topical formulations, beyond its nutritional benefits, Food and Chemical Toxicology, 108 (2017) 139-147.

[3] P. Marques, J. Marto, L. M. Gonçalves, R. Pacheco, M. Fitas, P. Pinto, M. L. M. Serralheiro, H. Ribeiro, Cynara scolymus L.: A promising Mediterranean extract for topical anti-aging prevention, Industrial Crops and Products, 109 (2017) 699-706.

[4] A. Raal, A. Orav, J. Nesterovitsch, K. Maidla, Analysis of carotenoids, flavonoids and essential oil of Calendula officinalis cultivars growing in Estonia, Natural Product Communications, 11(8) (2016) 1934578X1601100831.

[5] D. Villanueva-Bermejo, E. Vázquez, M. Villalva, S. Santoyo, T. Fornari, G. Reglero, M. Rodriguez GarcíaRisco, Simultaneous supercritical fluid extraction of heather (Calluna vulgaris L.) and marigold (Calendula officinalis L.) and anti-inflammatory activity of the extracts, Applied Sciences, 9(11) (2019) 2245-2254.

[6] S. S., Fatima, S. U. Govekar, K. V. Satardekar, S. S. Barve, P. P. Dhawal, In vitro analysis of ethanolic extract of flowers of Calendula officinalis for antioxidant, antimicrobial and UV- $\mathrm{H}_{2} \mathrm{O}_{2}$ induced DNA damage protection activity, Journal of Pharmacognosy and Phytochemistry, 7(5) (2018) 23782383.

[7] V. C. K. N. Deuschle, R. A. N. Deuschle, M. R. Bortoluzzi, M. L. Athayde, Physical chemistry evaluation of stability, spreadability, in vitro antioxidant, and photoprotective capacities of topical formulations containing Calendula officinalis L. leaf extract, Brazilian Journal of Pharmaceutical Sciences, 51(1) (2015) 63-75.

[8] C. Nicolaus, S. Junghanns, A. Hartmann, R. Murillo, M. Ganzera, I. Merfort, In vitro studies to evaluate the wound healing properties of Calendula officinalis extracts, Journal of Ethnopharmacology, 196 (2017) 94-103.

[9] T. K. Lim, Calendula officinalis, in Edible Medicinal And Non-Medicinal Plants, Springer, Dordrecht 2014, p. 213244.

[10] K. Gurzulov, M. Marčetić, D. Božić, Investigation of quality and antimicrobal activity of cultivated marigold flowers Calendula officinalis L, Medicinski Podmladak, 67(2) (2016) 73-79.
[11] Z. P. Rad, J. Mokhtari, M. Abbasi, Preparation and characterization of Calendula officinalis-loaded PCL/ gum arabic nanocomposite scaffolds for wound healing applications, Iranian Polymer Journal, 28(1) (2019) 51-63.

[12] J. Bernatoniene, R. Masteikova, J. Davalgiene, R. Peciura, R. Gauryliene, R. Bernatoniene, D. Majiene, R. Lazauskas, G. Civinskiene, S. Velziene, J. Muselik, Z. Chalupova, Topical application of Calendula officinalis (L.): Formulation and evaluation of hydrophilic cream with antioxidant activity, Journal of Medicinal Plants Research, 5(6) (2011) 868-877.

[13] N. Akhtar, B. A. Khan, M. Haji, S. Khan, M. Ahmad, F. Rasool, T. Mahmood, A. Rasul, Evaluation of various functional skin parameters using a topical cream of Calendula officinalis extract, African Journal of Pharmacy and Pharmacology, 5(2) (2011) 199-206.

[14] R. M. Daudt, P. I. Back, N. S. M. Cardozo, L. D. F. Marczak, I. C. Külkamp-Guerreiro, Pinhão starch and coat extract as new natural cosmetic ingredients: Topical formulation stability and sensory analysis, Carbohydrate Polymers, 134 (2015) 573-580.

[15] L. C. Cefali, J. A. Ataide, I. M. D. O. Sousa, M. C. Figueiredo, A. L. T. G. Ruiz, M. A. Foglio, P. G. Mazzola, In vitro solar protection factor, antioxidant activity, and stability of a topical formulation containing Benitaka grape (Vitis vinifera L.) peel extract, Natural Product Research, (2019) 1-6.

[16] S. A. Zerajic, I. M. Savić-Gajić, I. M. Savić, G. S. Nikolić, The optimization of ultrasound-assisted extraction of total flavonoids from pot marigold (Calendulae officinalis L.) flowers, Advanced Technologies, 8(1) (2019) 10-18.

[17] I. Savic Gajic, I. Savic, I. Boskov, S. Žerajić, I. Markovic, D. Gajic, Optimization of ultrasound-assisted extraction of phenolic compounds from black locust (Robiniae pseudoacaciae) flowers and comparison with conventional methods, Antioxidants, 8(8) (2019) 248-261.

[18] M. Z. Campanini, D. L. Custódio, A. L. Ivan, S. M. Martins, M. J. Paranzini, R. M. Martinez, W. A. Verri Jr., F. Vicentini, N. S. Arakawa, T. de J. Faria, M. M. Baracat, R. Casagrande, S. R. Georgetti, Topical formulations containing pimenta pseudocaryophyllus extract: In vitro antioxidant activity and in vivo efficacy against UV-B-induced oxidative stress, AAPS PharmSciTech, 15(1) (2014) 86-95.

[19] Pravilnik o kozmetičkim proizvodima (60/2019-4), "Službeni glasnik RS", broj 60 od 28. avgusta 2019. (In Serbian).

[20] D. Huang, B. Ou, R. L. Prior, The chemistry behind antioxidant capacity assays, Journal of Agricultural and Food Chemistry, 53(6) (2005) 1841-1856.

[21] N. A. Hernández-Rosas, J. C. García-Zebadúa, N. Hernández-Delgado, S. Torres-Castillo, P. FigueroaArredondo, R. Mora-Escobedo, Polyphenols profile, antioxidant capacity, and in vitro cytotoxic effect on human cancer cell lines of a hydroalcoholic extract from Calendula officinalis L. petals, TIP Revista Especializada en Ciencias Químico-Biológicas, 21(S1) (2019) 54-64.

[22] G. S. Ćetković, S. M. Djilas, J. M. Čanadanović-Brunet, V. T. Tumbas, Antioxidant properties of marigold extracts, Food Research International, 37(7) (2004) 643-650.

[23] S. Bissa, A. Bohra, Antibacterial potential of pot marigold, Journal of Microbiology and Antimicrobials, 3(3) (2011) 51-54.

[24] L. I. Wei, Y. Zhang, The antioxidation effect of Pyracantha fortuneana polyphenol in vitro, Science and Technology of 
Food Industry, 29(9) (2008) 121-123.

[25] S. Kamiloglu, A. A. Pasli, B. Ozcelik, J. Van Camp, E. Capanoglu, Influence of different processing and storage conditions on in vitro bioaccessibility of polyphenols in black carrot jams and marmalades, Food Chemistry, 186, (2015) 74-82.

[26] A.M. Oancea, C. Onofrei, M. Turturică, G. Bahrim, G. Râpeanu, N. Stănciuc, The kinetics of thermal degradation of polyphenolic compounds from elderberry (Sambucus nigra L.) extract, Food Science and Technology International, 24(4) (2018) 361-369.

[27] A. R. Bilia, M. C. Bergonzi, S. Gallori, G. Mazzi, F. F. Vincieri, Stability of the constituents of calendula, milkthistle and passionflower tinctures by LC-DAD and LCMS, Journal of Pharmaceutical and Biomedical Analysis, 30(3) (2002) 613-624.

[28] J. M. Roncero, M. Álvarez-Ortí, A. Pardo-Giménez, R. Gómez, A. Rabadán, J. E. Pardo, Virgin almond oil: Extraction methods and composition, Grasas y Aceites, 67(3) (2016) 143.

[29] Y. Sultana, K. Kohli, M. Athar, R. K. Khar, M. Aqil, Effect of pre-treatment of almond oil on ultraviolet B-induced cutaneous photoaging in mice, Journal of Cosmetic Dermatology, 6(1) (2007) 14-19.

[30] A. L. Bogdanov, Research on the effect of lanolin on rheological and tribotechnical characteristics of complex calcium grease, Journal of Friction and Wear, 40(3)
(2019) 266-269

[31] M. Fransen, L. E. Overgaard, J. D. Johansen, J. P. Thyssen, Contact allergy to lanolin: temporal changes in prevalence and association with atopic dermatitis, Contact Dermatitis, 78(1) (2018) 70-75.

[32] M. Schmidt, Boric acid inhibition of Trichophyton rubrum growth and conidia formation, Biological Trace Element Research, 180(2) (2017) 349-354.

[33] V. M. Di Mambro, M. J. Fonseca, Assays of physical stability and antioxidant activity of a topical formulation added with different plant extracts, Journal of Pharmaceutical and Biomedical Analysis, 37(2) (2005) 287-295.

[34] C. Anchisi, A. M. Maccioni, C. Sinico, D. Valenti, Stability studies of new cosmetic formulations with vegetable extracts as functional agents, II Farmaco, 56(5-7) (2001) 427-431.

[35] Z. Pazhohideh, S. Mohammadi, N. Bahrami, F. Mojab, P. Abedi, E. Maraghi, The effect of Calendula officinalis versus metronidazole on bacterial vaginosis in women: A double-blind randomized controlled trial, Journal of Advanced Pharmaceutical Technology \& Research, 9(1) (2018) 15.

[36] E. Saffari, S. Mohammad-Alizadeh-Charandabi, M. Adibpour, M. Mirghafourvand, Y. Javadzadeh, Comparing the effects of Calendula officinalis and clotrimazole on vaginal Candidiasis: A randomized controlled trial, Women and Health, 57(10) (2017) 1145-1160.

Izvod

\section{FIZIČKA, HEMIJSKA I ANTIOKSIDATIVNA STUDIJA STABILNOSTI TOPIKALNE FORMULACIJE NA BAZI EKSTRAKTA CVETA NEVENA (Calendula officinalis $L$.)}

Ivan M. Savić*, Ivana M. Savić Gajić

Tehnološki fakultet u Leskovcu, Univerzitet u Nišu, Bulevar oslobođenja 124, 16000 Leskovac, Srbija

Ekstrakt cveta nevena (Calendula officinalis L.) ima farmakološka svojstva zbog prisustva različitih bioaktivnih jedinjenja. Poznato je da ekstrakt ima antioksidativna, antiimflamatorna, antitumorska, antibakterijska, antifugalna, antivirusna, antimutagena, antidematitisna svojstva, itd. Cilj ovog rada bio je poboljšanje kvaliteta izabrane topikalne formulacije dodatkom etanolnog ekstrakta cveta nevena, kao i praćenje njene stabilnosti. Topikalna formulacija bila je emulzija voda-u-ulju pripremljena toplo/toplo emulzifikacionim procesom sa masnom fazom koja se sastojala od vazelina, lanolina i bademovog ulja. Ekstrakt pripremljen ultrazvučnom ekstrakcijom imao je sadržaj antioksidanasa 3,512 g ekvivalenta galne kiseline $100 \mathrm{~g}^{-1}$ suve mase i polovinu maksimalne inhibitorne koncentracije $0.14 \mathrm{mg} \mathrm{mL}^{-1}$ određena DPPH testom. Studija hemijske stabilnosti pokazala je da dnevna svetlost nema značajan uticaj na stabilnost antioksidanasa u ekstraktu, dok povećanje temperature dovodi do njihove degradacije. Rok trajanja ekstrakta je oko 8 meseci na $4{ }^{\circ} \mathrm{C}$ i 3 meseca na $22{ }^{\circ} \mathrm{C}$ (sobna temperatura). Pripremljene nekategorisane topikalne formulacije koje sadrže $1 \%$ i $2 \%(\mathrm{~m} / \mathrm{m})$ ekstrakta cveta nevena bile su stabilne na različitim temperaturama tokom čuvanja. Nekategorisane formulacije su pokazivale antioksidativnu aktivnost, ali se aktivnost ekstrakta u formulacijama smanjivala sa povećanjem temperature čuvanja. Ekstrakt cveta nevena i razvijene nekategorisane formulacije su pokazale inhibitornu aktivnost na Gram-pozitivnim (Staphylococcus aureus) i Gramnegativnim bakterijama (Escherichia coli, Proteus mirabilis, Klebsiella pneumoniae), kao i na Candida albicans. Nekategorisane formulacije sa ovom aktivnošću se mogu koristiti kod tretmana kožnih infekcija.
(ORIGINALNI NAUČNI RAD) UDK 633.88:66.061.3 DOI $10.5937 /$ savteh2101011S

Ključne reči: ekstrakt, emulzija, antioksidativna aktivnost, antimikrobna aktivnost, hemijska stabiljnost, kontrola kvaliteta. 